\title{
RELACJE POLSKI Z EUROPĄ WSCHODNIĄ (LITWĄ, LOTWĄ, ESTONIĄ, BIAŁORUSIĄ I UKRAINĄ) W XX I XXI WIEKU ORAZ ICH UWARUNKOWANIA WEWNĘTRZNE I MIĘDZYNARODOWE PRÓBA PODSUMOWANIA
}

Przedmiotem niniejszego tekstu jest próba podsumowania relacji w XXXXI stuleciu pomiędzy Polską a państwami Europy Wschodniej - definiowanej dla potrzeb poniższych rozważań jako obszar ograniczony od północy Zatoką Fińską, od południa Karpatami i Morzem Czarnym, zaś od strony zachodniej i wschodniej odpowiednio Morzem Bałtyckim i zmieniającą swój przebieg wschodnią granicą państwa polskiego oraz również zmienną zachodnią granicą Rosji Sowieckiej, a później Rosyjskiej Socjalistycznej Federacyjnej Republiki Sowieckiej. Warto zauważyć, iż w ogromnej większości państwa Europy Wschodniej powstawały na ziemiach i w oparciu o narody, które w okresie największej potęgi Rzeczypospolitej Obojga Narodów - na przełomie XVI i XVII w. - znalazły i kształtowały się w granicach tego nowożytnego wschodnioeuropejskiego mocarstwa, pozostając pod wplywami wypracowanego w dawnym Królestwie Polskim (Koronie) systemu politycznego i polskiej kultury.

W związku ze zmianami granic Polski oraz państwa sowieckiego w minionym stuleciu - skutkującymi okresową likwidacją suwerennego państwa ukraińskiego i białoruskiego, a następnie niepodległej państwowości litewskiej, łotewskiej i estońskiej - należy podkreślić, iż rozważania obejmować będą także zagadnienie relacji, zachodzących pomiędzy II Rzecząpospolitą, jak również tzw. Polską Ludową w latach 1945-1989, a sowieckimi republikami ukraińską i białoruską. Przedmiotem refleksji stanie się także stosunek państwa polskiego na emigracji oraz ośrodków i środowisk politycznych polskiego uchodźstwa po 1939 r. do zagadnienia państwowości ukraińskiej, białoruskiej oraz republik nadbałtyckich. 
Konieczne wydaje się przy tym, dla uzyskania pełnego obrazu zagadnienia, zasygnalizowanie jego międzynarodowych uwarunkowań oraz uwzględnienie wpływu na relacje międzypaństwowe kwestii wewnętrznych (związanych przede wszystkim z problematyką mniejszości narodowych).

\section{Narodziny w cieniu Wielkiej Wojny}

Świt minionego stulecia zastał okrzepłe i kształtujące się narody Europy Wschodniej pod panowaniem rosyjskiego imperium. W granicach państwa carów znajdowały się nie tylko terytoria zamieszkiwane przez reprezentujące różny poziom poczucia własnej tożsamości narody estoński, łotewski, białoruski i ukraiński, lecz także przez Polaków i Litwinów, pozbawionych własnej państwowości w wyniku rozbiorów i podziału terytorium dawnej Rzeczypospolitej pomiędzy Rosję, Prusy i Austrię u schyłku XVIII w.

Druga połowa XIX i początek XX stulecia stanowily dla Estończyków, Łotyszy, Białorusinów i Ukraińców okres narodzin nowoczesnej świadomości narodowej. W latach 1857-1861 ujrzał światło dzienne Kalevipoeg - estoński epos, stanowiący dla samych Estończyków symboliczny początek drogi do ukształtowania ich wspólnoty jako europejskiego narodu. Na połowę XIX w. datuje się również początek rozwoju narodowego ruchu Młodołotyszy, którego celem stało się rozbudzanie i pielęgnowanie świadomości narodowej wśród ludności łotewskiej oraz obrona narodowej odrębności i tożsamości. Z kolei przełom stuleci to czas, w którym zaczęla się kształtować elita kulturalna i polityczna Białorusinów, głosząca ideę odrębnego narodu białoruskiego. W 1902 r. Wacław Iwanowski założył Białoruską Partię Rewolucyjną. Rok później powstała Białoruska Socjalistyczna Hromada, która od 1906 r. dysponowała własnym tytułem - i zarazem pierwszą legalną białoruską gazetą - Nasza Dola. Prekursorzy i popularyzatorzy haseł odrębnych narodów - estońskiego, łotewskiego i białoruskiego musieli mierzyć się równocześnie z zagrożeniem, jakie stanowiła dla propagowanych przez nich idei polityka rusyfikacyjna carskiego imperium.

Wcześniej rozpoczęła się droga do narodowej samoidentyfikacji Ukraińców i Litwinów. O ile prekursorzy ukraińskiego nowoczesnego nacjonalizmu mogli doszukiwać się - po części tylko zasadnie - pierwocin narodowej wspólnoty ukraińskiej i korzeni, uwiarygadniających ukraińskie ambicje państwowotwórcze już w dziejach Kozaczyzny na południowo-wschodnich kresach Rzeczypospolitej Obojga Narodów oraz w średniowiecznej historii Rusi Kijowskiej i Księstwa Halicko-Wołyńskiego, o tyle narodziny nowoczesnej świadomości narodowej Ukraińców (mieszkających wówczas w austriackiej Galicji i w Rosji, czyli na ziemiach podzielonej w trakcie rozbiorów Rzeczypospolitej) należy 
umiejscowić w pierwszej połowie XIX stulecia. Za symboliczny początek tego procesu uznaje się opublikowanie jeszcze w 1798 r. w języku ukraińskim Eneidy przez Iwana Kotlarewskiego, a stymulowały go przez następne sto lat twórczość i działalność pisarza i poety Tarasa Szewczenki oraz historyka Mychajły Hruszewskiego, a także rusińskich (ukraińskich) struktur: Rady Ruskiej, oświatowej Proświty, skautowego Płasta, wreszcie partii i organizacji paramilitarnych. Aktywność na rzecz kształtowania świadomości narodowej Ukraińców, tolerowana w monarchii austro-węgierskiej, czyniąca z zamieszkiwanych przez nich obszarów Małopolski (Galicji) Wschodniej swoisty ukraiński Piemont, była zwalczana w carskim imperium, prącym do rusyfikacji ludności ukraińskiej.

Skomplikowany był proces budowy świadomości narodowej Litwinów. Do upadku Rzeczypospolitej Obojga Narodów Wielkie Księstwo Litewskie (którego początki sięgały XIII w.) stanowiło jej drugi - obok polskiej Korony - komponent. Jednak elity litewskie i ruskie Księstwa ulegały stopniowo kulturowej i politycznej polonizacji, dając początek warstwie, której przedstawicieli charakteryzowano, jako gente ruthenus, natione Polonus. Nowoczesna, ludowa świadomość narodowa Litwinów - w opozycji wobec rusyfikacyjnej polityki Rosji, ale i polskiej dominacji kulturowej - zaczęła rodzić się w ostatnich dekadach XIX w., a jej przejawem było m.in. pojawienie się litewskich czasopism: „Aušra” (jutrzenka), „Varpas” (dzwon) i „Ūkininkas” (rolnik) ${ }^{1}$.

Krwawą kolebką nowych - bądź odrodzonych - państw Europy Wschodniej miała się stać I wojna światowa. Na ziemiach estońskich, okupowanych wówczas przez Niemcy, 24 lutego 1918 r. powstał komitet, który proklamował niepodległość Estonii. Pierwszym premierem nowego państwa został Konstantin Päts. Również ziemie łotewskie w trakcie Wielkiej Wojny były częściowo okupowane przez Niemcy. Po zawarciu 3 marca 1918 r. traktatu pokojowego z Rosją Sowiecką w Brześciu przez Cesarstwo Niemieckie i Austro-Węgry oraz ich sojuszników Bułgarię i Turcję Berlin wyraził zgodę na utworzenie na Łotwie Rady Ludowej - przedstawicielstwa łotewskich partii politycznych. Powołała ona następnie rząd Kārlisa Ulmanisa, a 18 listopada 1918 r. proklamowana została niepodległość Łotwy.

Po traktacie brzeskim narodziło się także na obszarach Białej Rusi, zajętych przez Niemców, pierwsze $\mathrm{w}$ historii niepodległe państwo białoruskie, proklamowane 25 marca 1918 r. Utworzona wówczas Białoruska Republika Ludowa przetrwała zaledwie kilka miesięcy, kończąc swój żywot wraz z ewakuacją oddziałów niemieckich i równoczesnym zajmowaniem ziem BRL przez Armię Czerwoną. W styczniu 1919 r. bolszewicy ogłosili powstanie Białoruskiej Socjalistycznej Republiki Sowieckiej - formalnie niepodległej, w istocie

1 Więcej na ten temat w: B. Cywiński (2014): Dzieje narodów Europy Wschodniej. Szańce kultur, Editions Spotkania. 
jednak uzależnionej od Rosji Sowieckiej. Z kolei na Litwie, okupowanej przez Niemców, we wrześniu 1917 r. wybrano w Wilnie Radę Litewską tzw. Tarybę. Ta 16 lutego 1918 r. ogłosiła utworzenie niepodległego państwa litewskiego. Przeciwko władzy Rady wystąpiła Komunistyczna Partia Litwy, tworząc Tymczasowy Rząd Robotniczo-Włościański, a po wkroczeniu na Litwę Armii Czerwonej ogłaszając powstanie Litewsko-Białoruskiej Republiki Rad.

$\mathrm{Na}$ Ukrainie faktyczny rozkład monarchii habsburskiej u schyłku I wojny światowej umożliwił jesienią 1918 r. powołanie do życia w Małopolsce Wschodniej Zachodnioukraińskiej Republiki Ludowej, mającej w zamierzeniach jej twórców objąć obszary od Sanu po Zbrucz. Natomiast nad Dnieprem po wycofaniu się wojsk niemieckich i upadku proniemieckiego hetmanatu Pawła Skoropadskiego restytuowana została - utworzona jeszcze w styczniu 1918 r. po puczu bolszewickim w Rosji, a przejściowo obalona w wyniku zamachu stanu wspomnianego Pawła Skoropadskiego - Ukraińska Republika Ludowa. Obydwa państwa ukraińskie znalazły się od momentu powstania w ostrym konflikcie politycznym i militarnym: ZURL z odradzającą się Rzecząpospolitą, URL - z jednej strony z próbującymi przejąć władzę nad Dnieprem bolszewikami, z drugiej z wojskami białych, walczącymi z władzą sowiecką, ale również w imię powrotu emancypującej się Ukrainy w granice odnowionego rosyjskiego imperium ${ }^{2}$.

W listopadzie 1918 r. - wobec klęski państw centralnych, upadku Cesarstwa Niemieckiego i rozpadu Austro-Węgier, wreszcie puczu bolszewickiego i wojny domowej w Rosji - nastąpiło odrodzenie państwowości polskiej, a II Rzeczpospolita stała się zachodnim sąsiadem republik nadbałtyckich, Białorusi i dwóch państw ukraińskich. Sąsiedztwo to tworzyło zarówno perspektywy pokojowych relacji, jak i zaistnienia konfliktów, wywołanych sporami terytorialnymi. Cieniem na przyszłości regionu kładło się również sąsiedztwo Rosji Sowieckiej, która - aczkolwiek trawiona wojną domową - przejęla po dawnym państwie carów (i próbowała realizować) imperatyw polityki imperialnej i faktycznej dominacji Moskwy pod nowym hasłem - eksportu bolszewickiej rewolucji i totalitarnego systemu komunistycznego.

\section{Porządek (?) z chaosu}

Dla Europy Wschodniej koniec I wojny światowej nie oznaczał zakończenia działań wojennych. Początek relacji pomiędzy odradzającymi się i powstającymi państwami regionu zdominowały walki zbrojne o granice. Ich najważniejszym uczestnikiem - oprócz Rosji Sowieckiej - była II Rzeczpospolita.

2 Patrz też w: J. Pajewski (2005): Pierwsza wojna światowa 1914-1918, Warszawa; A. Chwalba (2014): Samobójstwo Europy. Wielka Wojna 1914-1918, Kraków. 
Od jesieni 1918 r. do lipca 1919 r. jej wojska biły się z oddziałami Zachodnioukraińskiej Republiki Ludowej o Małopolskę Wschodnią. Stawką w tej wojnie - zakończonej opanowaniem przez Polaków spornego obszaru - było z jednej strony przyłączenie Galicji Wschodniej z Lwowem do Rzeczypospolitej, z drugiej - przetrwanie ZURL ${ }^{3}$.

Wcześniej - w lutym 1919 r., gdy front wschodni opuszczały wojska niemieckie, rozdzielające dotąd wojska polskie i bolszewickie - rozpoczęła się wielka wojna polsko-sowiecka. Miała się ona toczyć przez ponad dwa lata, a teatrem działań wojennych, a zarazem przedmiotem konfliktu, była Wileńszczyzna, Białoruś i Ukraina Naddnieprzańska. Kreml dążył do ich zajęcia, zbolszewizowania i stworzenia $\mathrm{z}$ nich bazy do dalszego pochodu rewolucji proletariackiej w głąb Europy Środkowej i Zachodniej. Rzeczpospolita prowadziła wojnę w imię realizacji idei federalizmu, głoszonej przez ówczesnego Naczelnika Państwa i Wodza Naczelnego Józefa Piłsudskiego. Zakładała ona powstanie w Europie Środkowej i Wschodniej federacyjnego związku państwowego, w skład którego miały wejść Polska, Litwa, Białoruś i Ukraina. Jednak koncepcji tej nie udało się zrealizować. Litwini odrzucili propozycje federacyjne; propaństwowe, niepodległościowe elity białoruskie nie podołały ambitnemu wyzwaniu; wreszcie zbyt silnym przeciwnikiem okazało się dla Rzeczypospolitej i sprzymierzonej z nią Ukraińskiej Republiki Ludowej, państwo sowieckie. Polska dzięki zwycięstwom nad Wisłą i Niemnem obroniła niepodległość, lecz musiała zrezygnować z ambitnego planu budowy wielopaństwowej federacji. Obszary zachodniej Białorusi i Ukrainy zostały włączone w granice Rzeczypospolitej, wschodnie zaś - do zdominowanej przez Rosję sowieckiej federacji, w ramach której funkcjonowały jako pozbawione faktycznej politycznej podmiotowości Białoruska Socjalistyczna Republika Sowiecka i Ukraińska Socjalistyczna Republika Sowiecka. Wojnę polsko-sowiecką zakończył w 1921 r. traktat ryski, którego sygnatariuszami były z jednej strony Rzeczpospolita, z drugiej - Rosja Sowiecka i USRS ${ }^{4}$.

Pokłosiem wojen o granice na wschodzie kontynentu była także wrogość pomiędzy Polską i Litwą. Jesienią 1920 r. jednostki wojsk polskich - rzekomo zbuntowane w obliczu decyzji Warszawy, zakazującej wkroczenia na Wileńszczyznę (znajdującą się wówczas w rękach litewskich), w istocie działające za wiedzą Józefa Piłsudskiego - zajęły Wilno i Wileńszczyznę, zamieszkiwane przez polską większość. Na odebranych Litwinom obszarach powstała tzw.

${ }^{3}$ Zob.: M. Klimecki (2000): Polsko-ukraińska wojna o Lwów i Galicję Wschodniq 1918-1919, Warszawa.

${ }^{4}$ Patrz więcej w: N. Davies (2011): Orzet Bialy, czerwona gwiazda. Wojna polsko-bolszewicka 1919-1920, Kraków. 
Litwa Środkowa, której ziemie zostały w 1922 r. włączone w granice Rzeczypospolitej, stając się zarzewiem wieloletniego konfliktu polsko-litewskiego ${ }^{5}$.

Natomiast od początku okresu międzywojennego Warszawa nawiązała dobre relacje z pozostałymi republikami nadbałtyckimi. Wojska polskie wspierały armię łotewską podczas wojny o niepodległość Łotwy w latach 1918-1920, czym Polacy zaskarbili sobie wdzięczność Łotyszy. O dobre stosunki wzajemne zabiegała również Polska i Estonia. Obydwie republiki nadbałtyckie i Rzeczpospolita udzielały sobie przy tym wsparcia na forum międzynarodowym oraz zgodnie stawały się podmiotami wielostronnych porozumień. W 1922 r. wspólnie z Finlandią podpisały w Warszawie porozumienie, które miało dać początek tzw. Związkowi Bałtyckiemu, projektowanemu przez Polskę jako instrument wspólnej polityki bezpieczeństwa regionalnego w obliczu zagrożenia ze strony Rosji Sowieckiej. Porozumienie zawierało pakt o nieagresji i umożliwiało wzajemną pomoc w sytuacji zewnętrznego zagrożenia.

Wyrazem prowadzenia przez Warszawę, Rygę i Tallin skoordynowanej polityki zagranicznej było podpisanie przez Polskę, Łotwę i Estonię protokołu Litwinowa. Wcześniej Moskwa zaproponowała stronie polskiej podpisanie protokołu dwustronnego, według którego antywojenny pakt Brianda-Kellogga, odrzucający wojnę jako instrument polityki, nabrałby dla ówczesnego Związku Sowieckiego ${ }^{6}$ i Rzeczypospolitej mocy natychmiast po jego ratyfikacji przez oba państwa. Dyplomacja polska uzależniła jednak podpisanie protokołu od jego rozszerzenia na Estonię, Łotwę i swego strategicznego sojusznika - Rumunię.

$\mathrm{Na}$ tle dobrych relacji polsko-łotewskich i polsko-estońskich negatywnie wyróżniały się i kładły cieniem na wizerunku polityki polskiej wobec państw nadbałtyckich stosunki z Litwą. W konsekwencji wcześniejszego zajęcia Wilna i Wileńszczyzny przez wojska polskie, a następnie ich włączenia do Rzeczypospolitej, państwo litewskie ze stolicą w Kownie odmawiało zarówno nawiązania stosunków dyplomatycznych z Polską, jak i udziału w regionalnych porozumieniach, których była ona inicjatorem lub uczestnikiem. Władze litewskie utrzymywały, iż Wilno pozostaje stolicą państwa, a pomiędzy obydwoma państwami panuje faktycznie stan wojny. W $1926 \mathrm{r}$. Litwa zawarła pakt o nieagresji ze Związkiem Sowieckim. W tym samym roku doszło w Kownie do zamachu

5 O konflikcie polsko-litewskim m.in. w: P. Łossowski (1985): Po tej i po tamtej stronie Niemna. Stosunki polsko-litewskie 1883-1939, Warszawa.

6 Związek Sowiecki (Związek Socjalistycznych Republik Sowieckich) został utworzony w grudniu 1922 r. na mocy traktatu założycielskiego, zawartego przez rządzone przez bolszewików, lecz formalnie niepodległe: Rosję Sowiecką (Rosyjską Federacyjną Socjalistyczną Republikę Sowiecką), USRS, BSRS i Zakaukaską Federacyjną Socjalistyczną Republikę Sowiecką. 
stanu, w wyniku którego na czele państwa stanęli nastawieni zarazem antypolsko i proniemiecko prezydent Antanas Smetona i premier Augustinas Voldemaras. W 1927 r. spór polsko-litewski był omawiany na posiedzeniu Ligi Narodów, podczas którego zapytany przez Józefa Piłsudskiego, czy pomiędzy Polską i Litwą panuje pokój, czy stan wojny, premier Voldemaras stwierdzil, iż Litwa nie znajduje się w stanie wojny z Polską. Liga Narodów stwierdziła zatem, że stan wojny między obydwoma krajami został zniesiony i zaleciła bezpośrednie negocjacje w celu przywrócenia stosunków dyplomatycznych.

W istocie konflikt trwał jednak nadal. W $1938 \mathrm{r}$. w wyniku incydentu na granicy z Litwą zginął polski żołnierz, co zostało przez Warszawę wykorzystane do sformułowania pod adresem Kowna ultimatum z żądaniem podjęcia kontaktów dyplomatycznych, popartego postawieniem w stan gotowości wojsk polskich. Litwa przyjęła polskie ultimatum. Nawiązano stosunki dyplomatyczne, a następnie porozumiano się co do komunikacji drogowej i kolejowej orazłączności pocztowej i telefonicznej. Zawarto także umowę normującą stosunki handlowe.

W okresie dwudziestolecia międzywojennego na relacje pomiędzy Rzecząpospolitą a państwami Europy Wschodniej miało również - obok zasadniczych celów polityki zagranicznej i metod ich realizacji, a także uwarunkowań międzynarodowych (przede wszystkim sąsiedztwa i polityki państwa sowieckiego i Niemiec) - wpływ zagadnienie mniejszości narodowych. Polityka narodowościowa Estonii i Łotwy wobec Polaków mieszkających na ich obszarach (robotników szukających zatrudnienia w przemyśle stoczniowym; inteligencji skupionej w Tallinie, Dorpacie i Rydze oraz potomków polskiego ziemiaństwa) była poprawna. Natomiast wobec ludności polskiej na Litwie (wbrew zaniżonym szacunkom Kowna stanowiła ona najprawdopodobniej około $10 \%$ populacji) tamtejszy rząd prowadził politykę ograniczania jej praw. Dramatyczna była sytuacja Polaków w granicach białoruskiej i ukraińskiej republiki sowieckiej. Poddawani byli oni faktycznej rusyfikacji, białorutenizacji i ukrainizacji. Stali się również - podobnie jak przedstawiciele innych narodowości na Białorusi i Ukrainie - przedmiotem nasilających się prześladowań. Próby tworzenia w latach 20. minionego stulecia polskich regionów autonomicznych zostały zastąpione w następnej dekadzie polityką represji, eksterminacji i masowych deportacji ludności polskiej.

Równocześnie mniejszości litewska, białoruska i ukraińska zamieszkiwały KresyWschodnie Rzeczypospolitej-Wileńszczyznę, Polesie,Wołyńi Małopolskę Wschodnią - stanowiąc odpowiednio około $0,4 \%, 4 \%, 15 \%$ populacji. Zarówno liczni Ukraińcy, jak i Białorusini stanowili istotne zagadnienie w polityce narodowościowej Polski międzywojennej. Konflikty pomiędzy państwem polskim i wymienionymi mniejszościami generowały: głód ziemi panujący wśród Ukraińców i Białorusinów (ludności w przeważającej mierze wiejskiej), postępująca 
faktyczna polonizacja kresowego szkolnictwa (w wypadku Ukraińców również opór polskich władz przed powołaniem do życia ukraińskiego uniwersytetu) oraz nierównoprawne traktowanie Białorusinów i Ukraińców przez polskich urzędników. Ponadto nielegalne organizacje ukraińskie, zarówno narodowe (Ukraińska Wojskowa Organizacja i Organizacja Ukraińskich Nacjonalistów), jak i komunistyczne (Komunistyczna Partia Zachodniej Ukrainy, działająca w ramach Komunistycznej Partii Polski), postulowały oderwanie Małopolski Wschodniej i Wołynia od Rzeczypospolitej - nacjonaliści dążąc do budowy suwerennego państwa ukraińskiego, komuniści zmierzając do włączenia dzielnicy do USRS. Postulaty odłączenia ziem zamieszkiwanych przez Białorusinów od Polski i wcielenia ich do BSRS formułowała z kolei nielegalna Komunistyczna Partia Zachodniej Białorusi (w strukturach KPP). Na Kresach Wschodnich dochodziło z jednej strony do antypolskich wystąpień ukraińskich i białoruskich, z drugiej - prób ich pacyfikacji przez wojsko i policję7.

Lata międzywojnia zapisały się w historii jako okres nie zawsze zakończonych sukcesem prób budowania poprawnych, bądź nawet przyjaznych, relacji pomiędzy państwami odradzającymi się do niepodległego bytu (Polska, Litwa) lub powstającymi od podstaw (Łotwa, Estonia). Na przeszkodzie w osiągnięciu tego celu stanęly nie tylko konflikty graniczne i polityka wobec mniejszości narodowych, lecz także agresywna polityka Rosji Sowieckiej w regionie, która po I wojnie światowej uniemożliwiła realizację państwowotwórczych ambicji Ukraińców i Białorusinów.

\section{Katastrofa II wojny światowej}

Rozbiór i likwidacja Czechosłowacji w latach 1938-1939, a następnie napaść Niemiec, a później Związku Sowieckiego na Polskę we wrześniu 1939 r. (stanowiące, jak się okazało, pierwszy rozdział II wojny światowej) przesądziły nie tylko o przyszłości polskich Kresów Wschodnich, zamieszkiwanych przez ludność ukraińską i białoruską, ale również o losie republik nadbałtyckich.

$\mathrm{Na}$ ziemiach polskich okupowanych przez Związek Sowiecki przeprowadzone zostały w październiku 1939 r. - w atmosferze terroru i podsycania wrogości ukraińskiej i białoruskiej ludności wobec Polaków - wybory do Zgromadzeń Ludowych Zachodniej Białorusi i Zachodniej Ukrainy, które miały być próbą legitymizacji agresji 17 września. Obydwa zgromadzenia wystąpiły następnie do Rady Najwyższej ZSRS z prośbą o włączenie Zachodniej Białorusi

${ }^{7}$ Więcej w: A. Chojnowski (1979): Koncepcje polityki narodowościowej rządów polskich w latach 1921-1939, Wrocław. 
i Zachodniej Ukrainy odpowiednio w granice BSRS i USRS. Decyzja o aneksji została podjęta przez Radę Najwyższą w listopadzie. Równocześnie ZSRS przekazał Wileńszczyznę z Wilnem, zajętą po agresji na Polską, Litwie. Jednak już w czerwcu 1940 r. wojska Armii Czerwonej wkroczyły z kolei na Litwę, Łotwę i do Estonii. Państwa te zostały wcielone do Związku Sowieckiego i od tej pory funkcjonowały w jego granicach jako republiki sowieckie ${ }^{8}$.

W wyniku splotu międzynarodowych uwarunkowań - w obliczu okupacji ziem polskich i republik nadbałtyckich najpierw przez III Rzeszę i ZSRS (od 1941 r., po agresji hitlerowskiej na Związek Sowiecki w 1941 r. i wyparciu Armii Czerwonej na wschód - tylko przez Niemcy); nieukonstytuowania się przy tym politycznych reprezentacji (uznawanych rządów emigracyjnych) Litwy, Łotwy i Estonii na Zachodzie; wejścia Związku Sowieckiego w skład antyhitlerowskiej koalicji jako sojusznika Polski po jego zaatakowaniu przez III Rzeszę w 1941 r.; wreszcie zafunkcjonowania Litwy, Łotwy i Estonii (obok Ukrainy i Białorusi) jako republik sowieckich w granicach ZSRS - nie zaistniały w latach wojny relacje międzypaństwowe pomiędzy Polską a państwami Europy Wschodniej (poza Związkiem Sowieckim).

Nie oznaczało to jednak, że polscy politycy i publicyści oraz organy prasowe, reprezentujące stanowiska środowisk politycznych na emigracji i w okupowanym kraju, nie wypowiadały się na temat ówczesnej sytuacji i przyszłości regionu. W polskiej prasie emigracyjnej i wydawanej w podziemiu pod okupacją popularnością cieszył się pogląd o możliwości odzyskania niepodległości przez republiki nadbałtyckie (niekiedy również Ukrainę i Białoruś). Restytucja niepodległych republik nadbaltyckich oraz państw ukraińskiego i białoruskiego miała być przy tym rezultatem wzajemnego wyniszczenia się Niemiec i Związku Sowieckiego w wyniku krwawego, długotrwałego konfliktu na wschodzie. Ewentualnego odzyskania suwerenności przez Kowno, Rygę, Tallin, Kijów i Mińsk oczekiwano z nadzieją na budowę przyjaznych relacji międzypaństwowych. Projektowano również, iż państwa Europy Wschodniej wspólnie z Polską mogłyby stworzyć silny międzypaństwowy związek, oparty na porozumieniach politycznych, wojskowych i gospodarczych.

Tymczasem jednak relacje pomiędzy narodami w regionie nie układały się w sposób, który mógłby uprawdopodobnić podobne wizje. Na Wileńszczyźnie przekazanej przez ZSRS Litwie władze kowieńskie traktowane były jak nowy okupant, choć wskazywano również, iż włączenie Wilna i regionu w granice Litwy stanowi mniejsze zło w porównaniu z okupacją sowiecką. Po jej powrocie w 1940 r, a następnie zajęciu Litwy przez Niemców, relacje polsko-litewskie

8 Zob. np.: T. Snyder (2011): Skrwawione ziemie. Europa między Hitlerem a Stalinem, Warszawa. 
pogarszała działalność współdziałającej z hitlerowcami policji litewskiej, uczestniczącej w antypolskich i antyżydowskich prześladowaniach, represjach oraz akcjach eksterminacyjnych. Lata okupacji sowieckiej, a później niemieckiej na polskich Kresach Wschodnich przyczyniły się także do dramatycznego zaostrzenia stosunków polsko-ukraińskich. W latach 1939-1941 władze sowieckie celowo antagonizowały Ukraińców z Polakami, wykorzystując występujący już wcześniej konflikt narodowościowy oraz różnice społeczne pomiędzy polskimi panami i chłopską ludnością ukraińską. Po agresji niemieckiej uaktywniła się Organizacja Ukraińskich Nacjonalistów, dążąca do utworzenia narodowego państwa ukraińskiego, obejmującego obszary Małopolski Wschodniej i Wołynia. Jej szowinistyczna, antypolska propaganda przyczyniła się w 1943 r. do tzw. rzezi wołyńskiej, w trakcie której oddziały OUN i założonej przez jej aktywistów Ukraińskiej Powstańczej Armii (UPA), wspierane przez podburzoną ludność ukraińską, wymordowały około 60 tysięcy Polaków (mieszkańców wołyńskich wsi). Licznych mordów na Polakach Ukraińcy dopuszczali się także w Małopolsce Wschodniej. Celem tych działań, inspirowanych przez nacjonalistów spod znaku tryzuba, była brutalna czystka etniczna na zachodnich obszarach projektowanego przez nich państwa ukraińskiego, w wyniku której exodus ludności polskiej nastąpiłby także z terenów, których nie objęła ludobójcza akcja9.

Zakończenie II wojny światowej zastało republiki nadbaltyckie, Ukrainę i Białoruś w granicach Związku Sowieckiego i pod wpływami totalitarnej ideologii komunistycznej. O ile w wypadku republik sowieckich - ukraińskiej i białoruskiej - oznaczało to kontynuację sytuacji, w jakiej znaleźli się Ukraińcy i Białorusini po I wojnie światowej, o tyle dla Litwinów, Łotyszy i Estończyków koniec wojny i zdobycie przez ZSRS pozycji filaru antyhitlerowskiej koalicji, a zarazem sojusznika demokratycznego Zachodu, przypieczętowały i na dekady zakonserwowały utratę suwerenności, będąca wynikiem agresji sowieckiej 1940 r. W innej sytuacji znalazło się państwo polskie, które jako Polska Rzeczpospolita Ludowa (PRL) stało się wraz z innymi krajami Europy Środkowo-Wschodniej politycznym satelitą, wasalem komunistycznej Moskwy w granicach tzw. bloku wschodniego. W tych warunkach relacje powojennej Polski z sowieckimi wówczas republikami nadbałtyckimi, Białorusią i Ukrainą pozbawione zostały fundamentalnej wartości - faktycznej podmiotowości politycznej ich uczestników.

9 Patrz m.in.: G. Motyka (2011): Od rzezi wołyńskiej do akcji „Wista”. Konflikt polsko-ukraiński 1943-1947, Kraków. 


\section{Wspólnota niewoli}

Po II wojnie światowej początkowo oficjalne relacje Warszawy z sowieckimi republikami litewską, białoruską i ukraińską zdominowało zagadnienie przesiedleń ludności - przede wszystkim polskiej z dawnych Kresów Wschodnich II Rzeczypospolitej w granice powojennej Polski, ale także pozostających na jej obszarze Litwinów, Białorusinów i Ukraińców do republik sowieckich. Jeszcze we wrześniu 1944 r. uformowany przez komunistów Polski Komitet Wyzwolenia Narodowego, odgrywający rolę władzy tymczasowej na kontrolowanych przez nich ziemiach polskich, porozumiał się z rządami USRS, BSRS i Litewskiej Socjalistycznej Republiki Sowieckiej (LSRS) w sprawie wysiedleń ludności.

Po 1945 r. z tzw. Polski Ludowej przesiedlono na wschód około pół miliona ludzi zarówno narodowości litewskiej i białoruskiej, jak i ukraińskiej. Równocześnie analogiczną akcją jeszcze w 1944 r. objęto Polaków, mieszkających w granicach sowieckiej Litwy, Białorusi i Ukrainy. W jej ramach z samego Wilna i Wileńszczyzny trafilo do Polski ponad 150 tysięcy osób. Z BSRS wysiedlono w latach 1944-1946 blisko 230 tysięcy Polaków. Natomiast z zachodnich terenów USRS (przed II wojną światową południowo-wschodnich terenów II Rzeczypospolitej) przesiedlono do Polski blisko 800 tysięcy osób. Warto zauważyć, iż przez propagandę ówczesnych komunistycznych władz Polski przesiedlenia nazywane były fałszywie repatriacją, choć w istocie były ekspatriacją z obszarów zamieszkiwanych przez ludność polską od wielu pokoleń. Dodać przy tym trzeba, iż w odróżnieniu od władz sowieckiej Ukrainy rządzący republikami litewską i białoruską komuniści utrudniali rejestrację chętnych do wyjazdu, a następnie zablokowali wyjazd około połowy zarejestrowanych w obawie przed wyludnieniem obszarów wiejskich, które w sposób zwarty zasiedlała dotąd ludność polska. Równocześnie władze obydwu republik dążyły do zlituanizowania i zbiałorutenizowania Polaków, którzy pozostali w granicach LSRS i BSRS ${ }^{10}$.

W warunkach inkorporacji Litwy, Łotwy, Estonii, Białorusi i Ukrainy przez Związek Sowiecki oraz utraty faktycznej suwerenności przez Polskę, a zatem braku możliwości nieskrępowanego kształtowania stosunków międzypaństwowych, nie zanikły wszakże swobodne relacje pomiędzy instytucjami państwa polskiego i polskimi środowiskami politycznymi na uchodźstwie a kręgami politycznej emigracji z dawniej niepodległych państw Europy Wschodniej - przede wszystkim ukraińskiej. Trwały one od zakończenia II wojny światowej aż do przemian, jakie zaszły na obszarze Europy

10 G. Hryciuk (2005): Przemiany narodowościowe i ludnościowe w Galicji Wschodniej i na Wolyniu w latach 1931-1948, Toruń. 
Środkowo-Wschodniej u schyłku XX stulecia, związanych z upadkiem komunizmu, emancypacją polityczną i demokratyzacją państw bloku komunistycznego oraz rozpadem Związku Sowieckiego i odzyskaniem niepodległości przez Ukrainę, Białoruś oraz republiki nadbałtyckie. Zwieńczeniem tych relacji stała się choćby polsko-ukraińska deklaracja podpisana m.in. przez prezydenta Rzeczypospolitej Polskiej na uchodźstwie Edwarda Raczyńskiego i prezydenta emigracyjnej Ukraińskiej Republiki Demokratycznej Mykołę Liwyckiego w Londynie w 1979 r. Dokument pomijał kwestię ewentualnych sporów terytorialnych, podkreślając wspólny główny cel - wyzwolenie Polski i Ukrainy spod władzy sowieckiego imperializmu.

W koncepcjach polskich partii emigracyjnych nabierała również konkretnych kształtów wizja przyszłości relacji pomiędzy Polską a państwami wschodnioeuropejskimi, uniezależnionymi już od sowieckiej dominacji. Najpełniej prezentowały ją środowiska piłsudczykowskie skupione w Lidze Niepodległości Polski, powracające do koncepcji utworzenia w przyszłości Międzymorza - związku suwerennych państw Europy Środkowej i Wschodniej.

Ważnym emigracyjnym ośrodkiem polskiego życia polityczno-intelektualnego był paryski Instytut Literacki, wydawca słynnego periodyku Kultura, kierowany przez Jerzego Giedroycia, współpracujący z uznanymi politykami, myślicielami, pisarzami i publicystami nie tylko polskiego uchodźstwa - również z emigrantami ukraińskimi, białoruskimi i litewskimi, a także rosyjskimi. Właśnie w środowisku Instytutu Literackiego i Kultury narodziła się i najmocniej wybrzmiała doktryna ULB (Ukraina-Litwa-Białoruś). Opierała się ona na dwóch tezach. Pierwsza stwierdzała, iż Polacy powinni pogodzić się z aktualnymi granicami ich państwa i nie wysuwać żądań rewizjonistycznych wobec Ukrainy, Litwy i Białorusi. Druga wzywała ich do konsekwentnego poparcia idei niepodległości tych państw i umacniania związków Kijowa, Wilna i Mińska z zachodnią cywilizacją polityczną. Stanowisko to zostało bardzo pozytywnie odebrane przez emigrację, wywodzącą się z anektowanych przez Związek Sowiecki państw Europy Wschodniej ${ }^{11}$.

W drugiej połowie XX w. wspólnota losów Polaków, Ukraińców, Białorusinów i nacji nadbałtyckich, zniewolonych przez totalitarny komunizm i Związek Sowiecki; świadomość podobnego położenia oraz pragnień, związanych z dążeniem do uzyskania podmiotowości narodowej, do urzeczywistnienia zasad demokratycznych i związanych z przestrzeganiem przez władze praw obywatelskich, wreszcie - do realizacji ideału materialnego dobrobytu, odległego

11 Patrz: P. Waingertner (2015): Jerzego Giedroycia idea ULB - geneza, założenia, próby realizacji. Zarys problematyki, Studia z Historii Społeczno-Gospodarczej XIX iXX wieku, nr 15 . 
od codzienności życia obywateli sowieckich republik i satelickich państw bloku wschodniego, sprawiały, że konflikty i dotychczasowe uprzedzenia zeszly na dalszy plan. Za wyraz tej tendencji uznać można wzrost sympatii propolskich i zainteresowania polską kulturą wśród krytycznie nastawionych do komunistycznej rzeczywistości przedstawicieli elity litewskiej, białoruskiej i ukraińskiej - nie tylko emigrantów, ale również obywateli republik sowieckich.

\section{Powrót do Europy}

Przełom lat 80. i 90. minionego stulecia zaowocował upadkiem systemu komunistycznego w Europie Wschodniej i na obszarze Azji, który znalazł się wcześniej w granicach ZSRS; emancypacją polityczną spod wpływu Kremla i demokratyzacją państw bloku wschodniego, wreszcie rozpadem Związku Sowieckiego i odzyskaniem niepodległości przez państwa nadbałtyckie, Ukrainę i Białoruś oraz inne postsowieckie republiki. Erozję systemu komunistycznego i rozpad ZSRS przyśpieszył nieudany pucz zwolenników utrzymania starego tadu z sierpnia 1991 r., skierowany przeciwko ówczesnemu prezydentowi Związku Sowieckiego Michaiłowi Gorbaczowowi. Jeszcze w jego trakcie niepodległość ogłosiły Litwa, Łotwa i Estonia (później także inne republiki). W grudniu 1991 r. przywódcy Ukrainy, Białorusi i Rosji podpisali układ białowieski, skutkujący likwidacją ZSRS. Wydarzenia te stworzyły w Europie Wschodniej sytuację, w której suwerenna już Rzeczpospolita mogła nie tylko odbudować relacje $\mathrm{z}$ niepodległymi republikami nadbałtyckimi, ale również nawiązać podmiotowe stosunki z wolną i demokratyczną Ukrainą i Białorusią.

Polska natychmiast - jeszcze w sierpniu 1991 r. - uznała niepodległość Litwy, a na początku września nawiązała z nią stosunki dyplomatyczne. Oba państwa podpisały traktat o przyjaznych stosunkach i dobrosąsiedzkiej współpracy. Warszawa popierała też litewskie starania o przyjęcie do Paktu Północnoatlantyckiego i Unii Europejskiej. Po uzyskaniu członkostwa w NATO i UE przez Polskę i Litwę oba państwa współpracują ściśle i wspierają się wzajemnie zarówno w ramach Paktu, jak i Unii. Solidarnie opowiadają się także za rozszerzeniem obu międzynarodowych stowarzyszeń m.in. o Ukrainę, wzmocnieniem militarnym wschodniej flanki Paktu Północnoatlantyckiego oraz solidarną polityką energetyczną UE w obliczu imperialnych ambicji Rosji. Konsultują się równocześnie w kwestii litewskiej polityki narodowościowej, która w Warszawie bywa interpretowana jako ograniczająca prawa mniejszości polskiej. Bardzo dobre relacje łączą również Polskę z Łotwą i Estonią - zarówno dzięki członkostwu w NATO i Unii Europejskiej, jak i solidarnemu poparciu koncepcji wzmocnienia wojskowej obecności Paktu Północnoatlantyckiego na wschodzie kontynentu oraz jednomyślności 
Warszawy, Rygi i Tallina w kwestii konieczności prowadzenia solidarnej polityki energetycznej przez UE. Podobnie jak w wypadku stosunków polsko-litewskich Polskę, Łotwę i Estonię łączy chęć zabezpieczenia się przed agresywną polityką Moskwy (wzmacniana u Łotyszy i Estończyków obawą przed wykorzystywaniem przez wschodniego sąsiada argumentu obrony zamieszkującej oba państwach licznej mniejszości rosyjskiej).

Z kolei tyleż trafnym, co symbolicznym w kontekście historycznym otwarciem relacji Warszawy i Kijowa po upadku ZSRS było uznanie suwerenności Ukrainy przez Polskę jako pierwsze państwo na świecie. Oba państwa przyjęly jeszcze w 1991 r. deklarację, dotyczącą zasad i kierunków rozwoju wzajemnych stosunków. Natomiast w 1992 r. podpisały traktat o dobrym sąsiedztwie, przyjaznych stosunkach i wspólpracy, gwarantujący również nienaruszalność wspólnej granicy i wykluczający roszczenia terytorialne. W 1996 r. Warszawa i Kijów przyjęły także deklarację o strategicznym partnerstwie. Dobre wzajemne relacje znajdowały odzwierciedlenie w inicjatywach podejmowanych w zakresie współpracy energetycznej i wojskowej, we wspieraniu przez Polskę proeuropejskich ambicji Ukrainy (wyrażających się w dążeniu do podjęcia bliskiej współpracy z UE, mającej stanowić wstęp do przyszłej akcesji), wreszcie w popieraniu przez Warszawę dążeń Kijowa do włączenia się w transatlantycki system bezpieczeństwa oparty na NATO. Sympatią i poparciem w Polsce cieszyła się zarówno ukraińska pomarańczowa rewolucja (2004-2005), jak i Euromajdan (2013-2014). W obydwu tych wydarzeniach - traktowanych w Polsce jako wyraz prozachodnich i prodemokratycznych dążeń Ukraińców oraz ambicji wyjścia spod faktycznej hegemonii Kremla - istotną rolę w mediacjach politycznych odegrali polscy politycy. Rzeczpospolita nie uznaje również dokonanej przez Rosję aneksji Krymu i próby oderwania od Ukrainy Donbasu, uczestnicząc w politycznych, gospodarczych i wojskowych sankcjach, wprowadzonych wobec Moskwy. Równocześnie cieniem na stosunkach polsko-ukraińskich kładzie się skomplikowana historia polsko-ukraińskich relacji (m.in. inna ocena polskich rządów w Małopolsce Wschodniej i na Wołyniu w okresie II Rzeczypospolitej oraz rzezi wołyńskiej, ukraińskiego ruchu narodowego i UPA), jak również wzrost nacjonalistycznych i antypolskich nastrojów na Ukrainie.

Na tym tle współczesne stosunki polsko-białoruskie charakteryzuje brak obciążeń o charakterze historycznym. Polska uznał niepodległość państwa białoruskiego jeszcze w $1991 \mathrm{r}$. Rok później podpisany został przez obie strony traktat o dobrym sąsiedztwie i przyjaznej współpracy. Natomiast Warszawę i Mińsk dzieli obecna polityka wewnętrzna i zagraniczna Białorusi. Pierwszą charakteryzuje bowiem faktyczne zastępowanie demokracji systemem autorytarnym oraz ograniczanie praw polskiej mniejszości. Drugą - dążenie do politycznej, gospodarczej i wojskowej integracji z Rosją. 
W XX stuleciu dzieje stosunków Polski z państwami Europy Wschodniej oraz wzajemnych relacji pomiędzy Polakami i narodami zamieszkującymi wschód Starego Kontynentu pomiędzy Zatoką Fińską, Bałtykiem, Morzem Czarnym oraz zmieniającymi się w tym okresie historycznym granicami Rzeczypospolitej i Rosji (Związku Sowieckiego) to opowieść niezwykle interesująca, ale również dramatyczna.

$\mathrm{W}$ pierwszej połowie stulecia została ona naznaczona z jednej strony dwiema wojnami światowymi i rewolucją bolszewicką w Rosji, które odcisnęły wyjątkowo niszczycielskie piętno na regionie środkowo-wschodniej i wschodniej Europy (choć Wielka Wojna i rosyjska wojna domowa bialych z czerwonymi okazały się ostatecznie czynnikami sprzyjającymi wybiciu się Polski i części państw wschodnioeuropejskich na niepodległość), z drugiej - sprzecznymi priorytetami w polityce zagranicznej Polski i jej wschodnich sąsiadów, wyrażającymi się we wspólnej obawie przed rosyjskim, a później sowieckim imperializmem, a równocześnie $\mathrm{w}$ regionalnych partykularnych sporach i wojnach granicznych.

Druga połowa stulecia to początkowo okres zniewolenia Polski i jej wschodnich sąsiadów przez totalitarny Związek Sowiecki i głoszoną przez niego komunistyczną ideologię - sprzyjający wszak wytworzeniu się solidarnych dążeń niepodległościowych i umocnieniu świadomości wspólnoty losu narodów regionu. U schyłku XX w. w obliczu bankructwa komunizmu, upadku i rozpadu ZSRS oraz uzależnionego od Moskwy bloku wschodniego zapanowały warunki sprzyjające restytucji politycznej podmiotowości Polski i państw Europy Wschodniej. Równocześnie - w konsekwencji historycznych doświadczeń - nastąpiło ustanowienie pomiędzy nimi przyjaznych i dobrosąsiedzkich relacji oraz obranie przez region - z wyjątkiem Białorusi - wspólnego kursu na przyłączenie się do transatlantyckich struktur bezpieczeństwa Paktu Północnoatlantyckiego (w obawie przed recydywą rosyjskiej polityki imperialnej, a później już w obliczu jej faktycznego wystąpienia) oraz wspólnoty zachodnioeuropejskiej ( $w$ celu realizacji idei awansu cywilizacyjnego, rozwoju gospodarczego i społecznego dobrobytu).

Analiza polskiej regionalnej polityki zagranicznej oraz relacji łączących Polaków i narody Europy Wschodniej w minionym stuleciu (ich istoty oraz rozlicznych uwarunkowań), będąca celem niniejszego wydawnictwa, wydaje się $\mathrm{w}$ tym kontekście zadaniem tyleż fascynującym, co trudnym do realizacji, a nade wszystko pożytecznym z perspektyw zarówno międzynarodowej aktywności polskiej dyplomacji, jak i budowy świadomości wagi wzajemnych relacji z narodami Europy Wschodniej wśród Polaków. 